\title{
Comparative phytochemical screening of kenaf and jute leaves
}

\begin{abstract}
This study was conducted to evaluate the comparative phytochemical composition of kenaf and jute leaves. The leaves were harvested at maturity, washed, dried, ground to powder and subsequently subjected to quantitative and qualitative phytochemical screening according to the standard protocols. The results showed that jute leaf contained significantly higher saponin, tannin and glycoside than kenaf leaf. Similarly, jute leaf recorded higher level $(25.00 \mathrm{mg} / 100 \mathrm{~g})$ of flavonoid than kenaf leaf $(20.00 \mathrm{mg} / 100 \mathrm{~g})$. In contrast, kenaf leaf recorded slightly higher level of steroid $(0.002 \%)$, and alkaloid $(0.28 \%)$ when compared with jute leaf with $0.001 \%$ for steroid and $0.25 \%$ for alkaloid. Kenaf leaf contained $569.55 \mathrm{mg} / 100$ gcarotenoidwhile jute leaf had $546.70 \mathrm{mg} / 100 \mathrm{~g}$ carotenoid. These leaves appeared to be rich in phytochemicals and antioxidants which are good either for human nutrition or medicinal purpose. Screening for the best extraction-solvent showed that water extracted most phytochemicals in both kenaf and jute leaves. Ideally, lipophilic phytochemicals are extracted with protic solvents while hydrophilic phytochemicals efficiently extracted with distilled water in order to retain their physico-chemical properties.
\end{abstract}

Keywords: Kenaf, phytochemical, jute, solvent
Volume 8 Issue 5 - 2018

\author{
Omenna EC,' Ojo $\mathrm{Al}^{2}$ \\ 'Kenaf and Jute, Improvement Programme, Obafemi Awolowo \\ University P.M.B.5029, Nigeria \\ ${ }^{2}$ Federal College of Agriculture, Moor Plantation, Nigeria
}

Correspondence: Omenna EC, Kenaf and Jute Improvement Programme, Institute of Agricultural Research and Training, Obafemi Awolowo University P.M.B.5029, Moor Plantation, Ibadan, Nigeria, Tel +2348039334092,

Email emmanuelomenma@gmail.com

Received: July 30, 2018 | Published: October 22, 2018

\section{Introduction}

Many leafy vegetables are mainly consumed for their nutritional values without much consideration for their medicinal importance. Butonly few species have been explored for its chemical and biological studies. Plants contain chemical substances and most of which are non-nutritive dietary components that are beneficial to human health. These components are called phytochemicals. "Phyto" means that they are plant derivative. ${ }^{1}$ Phytochemicals are chemical compound formed during plant's normal metabolic process. These chemicals are often referred to as secondary metabolite of which they are several classes including alkaloids, flavonoids, coumarins, steroids, glycosides, gum, phenol, tannins, terpenes and terpenoids. ${ }^{2}$ Phytochemical analyses are of paramount importance for the identification of new sources of therapeutically and industrially valuable compounds with medicinal significance and for the best and most judicious use of naturally available materials. ${ }^{3}$

In humans, numerous phytochemicals have been found to be protective and preventive against many degenerative diseases and pathological processes such as: ageing, coronary heart disease, Alzheimer's disease, neurodegenerative disorders, atherosclerosis, cataracts, and inflammation. ${ }^{4}$ Epidemiological and clinical studies provided evidence that most of these phytochemicals exhibit their protective and disease-preventing functions through their antioxidant activities. ${ }^{5}$ In addition, vegetables possess compounds that are essential for their medicinal values, human productive well-being and healthy lifestyle. Most plant leaves are used as medicine while their nutritional potentials are yet to be discovered. The medicinal values of vegetables are due to their phytochemical and other chemical constituents. ${ }^{6}$

Recent study showed that jute leaves contain appreciable amount of micronutrients, economic value, proximate compositions and other health benefits while kenaf was reported to possess different medicinal values. For instance, Alexopoulou et al. ${ }^{7}$ reported that kenaf leaf was applied to Guinea worms and the stem bark has been used for anaemia in Africa. In addition, Jaihyunk et al. ${ }^{8}$ reported the presence of phyto compounds in the hexane extracts of the different parts of the kenaf plant by GC-MS analysis. This publication suggested that phytol andlinolenic acid content of kenaf leaf and stem may be responsible for its medicinal properties. Furthermore, in Ayurvedic medicine, the kenaf leaves are used for bilious, blood, diabetes, coughsand throat disorders. ${ }^{7,9,10}$ Jute leaves (locally called Ewedu by Yorubas) is commonly used as vegetable in the South western part of Nigeria. Kenaf (Hibiscus cannabinus L.) is an annual herbaceous fibre crop and belongs to the same family of Malvaceae with jute mallow (Corchorusolitorius), cotton (Gossypium hirsutum L), and okra (Abelmoschus esculentus $\mathrm{L}$ ).

However, in Nigeria today, kenaf has been accepted as an industrial crop only but it is disheartening to note that kenaf is grossly underutilized in the pharmacological industries as well as in food and nutrition sciences. Presently, there is paucity of information on the phytochemical compositions of kenaf in relation to jute and hence their leaves are under-utilized.It is important to assess the phytochemical compositions of jute and kenaf leaves as a gateway to popularize its medicinal and nutritional uses.

\section{Methodology}

\section{Alkaloid determination}

Five grams of each sample of kenaf leaf and jute leaf were weighed into a $250 \mathrm{ml}$ beaker and $200 \mathrm{ml}$ of $10 \%$ acetic acid in ethanol were added and covered and allowed to stand for $4 \mathrm{hrs}$. This was filtered and the extract was concentrated on a water bath to one-quarter of the original volume. Concentrated ammonium hydroxide was added drop wise to the extract (and ammonium hydroxide was added drop wise to the extract) until the precipitate was completed. The whole solution was allowed to settle and alkaloid precipitated. The precipitate was washed with dilute ammonium hydroxide then filtered. The residue is 
the alkaloid which was dried and weighed according to the protocol described by Harborne ${ }^{11}$.

\section{Saponin determination}

The kenaf and jute leaf samples were pound differently and $20 \mathrm{~g}$ of each were put into a conical flask and $100 \mathrm{~cm}^{3}$ of $20 \%$ aqueous ethanol were added. The samples were heated over a hot water bath for $4 \mathrm{hrs}$ with continuous stirring at about $55^{\circ} \mathrm{C}$. The mixture was filtered and the residue re-extracted with another $200 \mathrm{ml} 20 \%$ ethanol. The combined extracts were reduced to $40 \mathrm{ml}$ over water bath at about $90^{\circ} \mathrm{C}$. The concentrate was transferred into a $250 \mathrm{ml}$ separation funnel and $29 \mathrm{ml}$ of diethyl ether was added and shaken vigorously. ${ }^{12}$

\section{Tannin determination}

$500 \mathrm{~g}$ of each leaf sample were weighed into a $50 \mathrm{ml}$ plastic bottle. $50 \mathrm{ml}$ of distilled water were added and shaken for $1 \mathrm{hr}$ in a mechanical shaker. This was filtered into a $5 \mathrm{oml}$ volumetric flask and made up to the mark. Then $5 \mathrm{ml}$ of the filtrate werepipetted out into a test tube and mixed with $2 \mathrm{ml}$ of $0.1 \mathrm{~m}$ feed in $0.1 \mathrm{~N} \mathrm{HCl}$ solution and $0.008 \mathrm{~m}$ potassium ferro-cyanide. The absorbance was measured at $120 \mathrm{~nm} .{ }^{13}$

\section{Glycosides determination}

$5 \mathrm{~g}$ of each sample was weighed into a beaker and $100 \mathrm{ml}$ of distilled water were added. The sample were soaked for $3 \mathrm{hrs}$ and filter to get filtrate. $1 \mathrm{ml}$ of filtrate were pipetted into a test tube, $2 \mathrm{ml}$ of 3,5-DNS (dinitrosalic acid) were added and boiled in a water bath for $10-15$ minutes, the mixture was allowed to cool in the test tube and $10 \mathrm{ml}$ distilled water were added and the absorbance at $540 \mathrm{~mm}$ for glycoside were read up. Percentage glycoside will be determined using the formula:

$$
\% \text { Glycoside }=\frac{\text { Mean absorbance } x \text { Volof extract } x 100}{1000 \times \text { waight of leaf sample }}
$$

\section{Flavonoid determination}

The total flavonoid content (TFC) content of kenaf and jute leaves was determined by Zhishen et al. ${ }^{14} 10 \mathrm{~g}$ of each sample was extracted with $100 \mathrm{ml}$ of $80 \%$ methanol. About $0.2 \mathrm{ml}$ was added to $4 \mathrm{ml}$ doubledistilled waterand $0.3 \mathrm{ml}$ of $5 \% \mathrm{NaNO}_{2}$ to the flask. The samples were maintained for $5 \mathrm{~min}$, and $0.3 \mathrm{ml}$ of $10 \% \mathrm{AlCl}_{3}$ was added. After $6 \mathrm{~min}$, $2 \mathrm{ml} \mathrm{NaOH}$ and fill double-distilled water up to $10 \mathrm{ml}$. The absorbance was measured at $510 \mathrm{~nm}$. TFC was calculated using a calibration curve of quercetin equivalents.

\section{Qualitative analysis}

Ten grams $(10 \mathrm{~g})$ of kenaf and jute leaves were weighed into four different labelled conical flasks. $100 \mathrm{ml}$ of the four different solvents (distilled water, methanol, ethanol and ethyl acetate) were poured into the four different conical flasks to extract the phytochemicals. After $24 \mathrm{hrs}$, the mixtures were filtered using what man filter paper (No.1) into conical flasks. The filtrates were concentrated by placing the flasks into water bath at $100^{\circ} \mathrm{C}$. The resulting filtrate were cooled to room temperature, Qualitative tests were then conducted on the cool solution as prescribed by Azubuogu ${ }^{15}$.

\section{Preparation of wagner reagent}

$13 \mathrm{~g}$ of iodine crystal and $2.0 \mathrm{~g}$ of potassium iodide were dissolved in water in a $100 \mathrm{ml}$ volumetric flask and the solution was made up to $100 \mathrm{ml}$.

\section{Preparation of mayer's reagent}

$1.3 \mathrm{~g}$ of mercuric chloride and $5.0 \mathrm{~g}$ of potassium iodide were dissolved in distilled water in a $100 \mathrm{ml}$ volumetric flask and the solution was made up to $100 \mathrm{ml}$.

Test for Alkaloids: (a) $1 \mathrm{ml}$ of $1 \% \mathrm{HCl}$ was added to $3 \mathrm{ml}$ of each of the extracts in a test tube. The mixture was heated for $20 \mathrm{mins}$ in a water bath. While heating, it was shaken continuously. The mixture was cooled and filtered. The procedure was repeated with each extract. (b) $1 \mathrm{ml}$ of each filtrate from (a) above was added to $0.5 \mathrm{ml}$ of Mayer's reagent.

Observation: A creamy colour change. (c) When $1 \mathrm{ml}$ of each filtrate from (a) above was added to $0.5 \mathrm{ml}$ of Wagner's reagent.

Observation: A brown colour precipitate.

Test for saponin: (a) Frothing test: $3 \mathrm{ml}$ of each extract and dilute with $2 \mathrm{ml}$ of distilled water was added in a test tube. The mixture was shaken vigorously.

Observation: A persistent frothing was observed. The frothing was persistence in the extract.

Note: forth is a mass of small bubbles especially on the surface of a liquid.

(b) Emulsion Test: $3 \mathrm{ml}$ of each extract was added to 5 drop of Olive oil in a test tube and the content was vigorously shaken.

Observation: Emulsification was observed which indicates the presence of saponin.

Test for flavonoids: $3 \mathrm{ml}$ of each extract was added to $10 \mathrm{ml}$ of distilled water the solution was shaken. $1 \mathrm{ml}$ of $10 \% \mathrm{NaOH}$ solution was added to the mixture.

Observation: Yellow coloration was observed. Absence of yellow coloration in the mixture indicates that flavonoid was not present.

Test for Steroids: Salkowski Test: 5 drops of concentrated $\mathrm{H}_{2} \mathrm{SO}_{4}$ were added to $1 \mathrm{ml}$ of each extract in a separate test tube.

Observation: A red coloration was observed indicating the presence of steroid.

Test for Tannin: $2 \mathrm{ml}$ of each extract in a separate test tube were boiled gently for $2 \mathrm{~min}$ and allowed to cool. 3 drop of ferric chloride solution were added to each extract

Observation: Orange coloration was observed.

Glycosides: $1 \mathrm{ml}$ of aqueous extract was mixed with $1 \mathrm{ml}$ of $20 \%$ solution of 3,5-dinitrosalic acid in methanol and $1 \mathrm{ml}$ of a $5 \%$ aqueous $\mathrm{NaOH}$ was added.

Observation: An immediate bright orange colour was observed indication of the presence of cardenolides in the extract. The colour fades gradually through reddish brown to brownish yellow. And it indicates the presence of glycosides. Heat in boiling water to get brick red coloration.

\section{Results and discussion}

The role of extraction-solvent is important in phyto-screening. Naturally, water- soluble phytochemicals like flavonoids are best extracted with water as to retain the physicochemical properties of 
phytochemicals while lipophilic phytochemicals are effectively extracted with protic solvents such as ethyl acetate among others. The results in Table 1A showed that the effect of the four solvents on the extraction of phytochemical from kenaf and jute leaves. Ethanol and methanol extracted saponin, and tannin, ethyl-acetate extracted alkaloid, saponin, glycoside and tannin, and water extracted saponin, flavonoids steroids and glycosides. In all the solvents used, only water extracted most of the phytochemicals in jute leaves, the reason may be that water is an universal polar solvent. On the other hand, the results in Table 1B showed that the effect of the four solvent on the extraction of phytochemical kenafleaf. Ethanol and methanol extracted saponin and tannin. Ethyl-acetate extracted alkaloid, glycoside, saponin and tannin and lastly water extracted flavonoids, alkaloid, saponin and glycoside. From the result table water and ethyl-acetate extracted most of the phytochemicals in the kenaf leaf sample.

Table IA Qualitative phytochemical screening of jute leaf extract from different solvents

\begin{tabular}{lllll}
\hline $\begin{array}{l}\text { Parameterl } \\
\text { Solvent }\end{array}$ & $\begin{array}{l}\text { Distilled } \\
\text { water }\end{array}$ & Ethanol & Ethyl-acetate & Methanol \\
\hline Alkaloids & - & - & + & - \\
Flavonoids & +++ & - & - & - \\
Glycoside & ++ & - & + & - \\
Saponin & + & + & ++ & + \\
Steroids & + & - & - & - \\
Tannin & - & + & ++ & + \\
\hline
\end{tabular}

Table IB Qualitative phytochemical screening of kenaf leaf extract from different solvents

\begin{tabular}{lllll}
\hline $\begin{array}{l}\text { Parameterl } \\
\text { Solvent }\end{array}$ & $\begin{array}{l}\text { Distilled } \\
\text { water }\end{array}$ & Ethanol & Ethyl-acetate & Methanol \\
\hline Alkaloids & + & - & + & - \\
Flavonoids & +++ & - & - & - \\
Glycoside & ++ & - & + & - \\
Saponin & + & + & +++ & + \\
Steroids & - & - & - & - \\
Tannin & - & + & ++ & + \\
\hline
\end{tabular}

Key + Means present, ++ mildly present, +++ densely present, __ absent

The results in Table 2 showed that the alkaloid content in kenaf leaf was significantly higher than that of jute leaf. This finding supported the publication report by Okoye \& Ebeledike ${ }^{16}$ that the presence of alkaloids signified the possession of medicinal properties within the leaves. However, thesaponin content of jute leaf was slightly higher than that of kenaf leaf. But the two leaves under investigation appeared to possess lower level of saponin compared to moringa oleifera and Azadirichta indica leaves. ${ }^{15}$ Similar trend of values was observed for the tannin in which jute leaf had $0.01 \%$ while kenaf leaf had $0.003 \%$. This result was significantly lower than $0.08 \%$ tannin reported for Moringa oleifera and Azadirichta indica leaves by Azubuogu. ${ }^{15}$ In fact, these results were in strong agreement with the data reported on the phytochemical constituents of Piper guineense (Uziza) by Okoye and Ebeledike. ${ }^{16}$ The outcomes of this research work uphold the assertion from the study of related literature that leaves should continue to be used as food since it contains valuable vitamins and minerals. Similarly, jute leaf contained slightly higher flavonoids and glycoside compared to kenaf leaf. Conversely, the level of glycoside obtained in kenaf and jute leaves were significantly higher than the $0.005 \%$ glycoside recorded for Moringa oleifera leaves by Azubuogu ${ }^{15}$. The observation of this study supported many literatures that the extracts exhibited antibacterial activity due to the presence of tannins, saponinand alkaloids. ${ }^{8}, 17$ Jute leaf appeared to be a rich source of flavonoids which inhibit free radical chains reactions and flavonoids possess antioxidant activity and equally anti-inflammatory and antiviral have the ability to lower cholesterol level. ${ }^{16}$ On the other hand, kenaf leaf recorded higher level of carotenoid and steroid than jute leaf. However, both jute and kenaf leaves proved to be the potential sources of carotenoids which are precursor for retinol synthesis (vitamin A). Carotenoid is also antioxidant and it plays essential role in scavenging free radicals which cause degenerative diseases. The phenolic and flavonoid compounds present in the plant tissue suggest its medicinal importance. ${ }^{10,12,18}$ The results of this study strongly supported the publication report by Jaihyunk et al. ${ }^{8}$ that the functional groups in phenolic and flavonoids compounds present in the kenaf plant exhibit antioxidant properties and inhibit the angiotensin I-converting enzyme and lipid peroxidation. From the results of this study, it can be concluded that kenaf and jute leaves contain phytochemicals (flavonoid, alkaloids, tannin, glycosides, carotenoid, saponin, and steroids). These leaves are rich in phytochemicals and antioxidants may be explored for their nutritional and health benefits. 19,20

Table 2 Comparative phytochemical content of kenaf and jute leaves

\begin{tabular}{lll}
\hline Phytochemical & Kenaf leaf & Jute leaf \\
\hline \% Alkaloid & $0.28^{\mathrm{a}}$ & $0.25^{\mathrm{b}}$ \\
\%Saponin & $0.15^{\mathrm{b}}$ & $0.16^{\mathrm{a}}$ \\
\%Tannin & $0.003^{\mathrm{b}}$ & $0.0 \mathrm{I}^{\mathrm{a}}$ \\
\%Glycoside & $0.10^{\mathrm{b}}$ & $0.1 \mathrm{I}^{\mathrm{a}}$ \\
\%Steroid & $0.002^{\mathrm{a}}$ & $0.00 \mathrm{I}^{\mathrm{b}}$ \\
Flavonoid(mg//00g) & $20.00^{\mathrm{b}}$ & $25.00^{\mathrm{a}}$ \\
Carotenoid(mg//00g) & $569.55^{\mathrm{a}}$ & $546.7^{\mathrm{b}}$ \\
\hline
\end{tabular}

Values are means $\pm S D$ of triplicate determination. Values with the same letter in a row are not significantly different $(P<0.05)$

\section{Acknowledgements}

None.

\section{Conflict of interest}

Authors declare that there is no conflict of interest.

\section{References}

1. Pamplona-Roger GD. Encyclopaedia of Food sand Their Healing Power. Pradillo: Editorial Safeliz SL. Plant Sciences. 2005;164:35-41.

2. Caragay AB. Cancer preventing foods and ingredients. Food Technology. 1992;46(4):6568.

3. Furumoto T, Wang R, Okazaki K, et al. Antitumor Promoters in Leaves of Jute. (Corchorus capsularis, Corchorus olitorius). Food Sci Technol Res. 2002;8(3):239-243. 
4. Birth DA. Journal of the American Dietetic Association. 2006;106:20-24.

5. Usoh IF, Akpan EJ, etim EO, et al. Antioxidant actions of dried flower extracts of hibiscus sabdariffa L. On sodium arsenite - induced oxidative stress in rats. Pakistan journal of Nutrition. 2005;4(3):135-141.

6. Ghafar SAA, Ismail M, Yazan LS, et al. Cytotoxic activity of kenaf seed oils from supercritical carbon dioxide fluid extraction towards human colorectal cancer (HT29) cell lines. Evid Based Complement Alternat Med. 2013;549-705.

7. Alexopoulou E, Papattheohari Y, Christou M, et al. Kenaf: A multipurpose crop for sever industrial applications. London, Springer-verlag; 2013. p. 1-15.

8. Jaihyunk R, Soon-Jae K, Joon-Woo A, et al. Phytochemicals and antioxidant activity in the kenaf plant (Hibiscus cannabinus L.). J Plant Biotechnol. 2017;44:191-202

9. Khare CP. Indian medicinal plants: An illustrated dictionary. London: Springer-verlag; 2007. 309 p.

10. Jin CW, Ghimeray AK, Wang L, et al. Far infrared assisted kenaf leaf tea preparation and its effect on phenolic compounds, antioxidant and ACE inhibitory activity. J Med Plants Res. 2013;7(17):1121-1128.

11. Harbone JB. Phytchemical Methods: A Guide to Modern Techniques of plant Analysis. London: Chapman A and Hall; 1973.

12. Kobaisy M, Tellez MR, Webber CL, et al. Phytotoxic and fungitoxic activities of the essential oil of kenaf (Hibiscus cannabinus L.) leaves and its composition. J Agric Food Chem. 2001;49(8):3768-3771.
13. Sarker SD. Nahar L. Chemistry for pharmacy students. General, Organic. John Wiley \& Sons, Ltd; 2007

14. Zhishen J, Mengcheng T, Jianming W. The determination of flavonoid contents in mulberry and their scavenging effects on superoxide radicals. Food Chem. 1999;64(4):555-559.

15. Azubuogu CU. Phytochemical analysis of Moringa oleifera and Azadrichta indica leaves. A project submitted to department of chemical engineering, caritas university, Enugu Nigeria. 2012.

16. Okoye EI, Ebeledike AO. Phytochemical constituents of piper guneense (uziza) and their health implications on some micro-organisms. Global Research Journal of Science. 2013;2(2):42-46.

17. Yao X, Li L. Wang N. New use of saponin compound for treating cardiovascular disease. CN Patent. 2005;1:562-564

18. Nyam KL, Tan CP, Lai OM, et al. Physicochemical properties and bioactive compounds of selected seed oils. Food Sci Techol. 2009;42(8):1396-1403.

19. Seddon JM. For the eye disease case-control study group. Dietary carotenoids, vitamins A, C and E and advanced age-related macular degeneration. Journal of American Medical Association. 1994;272(18):1413-1420.

20. Webber CL. Crude protein and yield components of six kenaf cultivars as affected by cropmaturity. Ind Crops Prod J. 1993;2(1):27-31. 